\title{
THE BIRTH OF A CHILD AS EXPERIENCED AND NARRATED IN THE 1990s FINLAND
}

\author{
Lena Marander-Eklund \\ PhD, Professor \\ Department of Folklore, Åbo Akademi University, Turku, Finland \\ lena.marander-eklund@abo.fi
}

\begin{abstract}
In this article, I examine the way Swedish-speaking first-time mothers living in Finland narrate their experience of giving birth between 1993 and 1997. The object is narrating about the moment of birth and experiential dimension of giving birth. This includes an analysis of stylistic means used in narration, and the points of narration. The material consists of childbirth stories told by 14 Swedish-speaking first-time mothers in interviews during the 1990s. I define the story as a personal experience narrative. The stories show that the women's experience is embodied. The birth-givers are more focused on giving birth than giving birth to a child and they relate to ambient norms and values in their narration.
\end{abstract}

Keywords: childbirth narratives, experience, interviews, narration, narrative style

\section{INTRODUCTION}

“And so, then and... but then he finally arrived."(IF mgt 1994/55)

The quote is a part of a childbirth story by Carita, one of my interviewees, describing the experience of birth. The narrative is constructed from many details and by dramatic means, but nonetheless it seems that Carita herself has little to tell when describing the moment of birth. Birth does not become the climax of the story, even though it would be natural to expect so. The peak of the story does not coincide with the peak of the experience.

In this article, I examine the way first-time mothers narrate their experience of the moment of giving birth. The object is, on the one hand, telling about the moment of birth and, on the other hand, the experiential dimension of birth. My material ${ }^{1}$ consists of childbirth stories told by 14 Swedish-speaking firsttime mothers in interviews conducted in Finland in the 1990s. The names I have given the interviewees are encrypted, based on the alphabet in the order 
that I interviewed them (Anita, Benita, Carita, and so on). The mothers lived in Turku and Parainen, and I contacted them through maternity counselling services in both cities. The women decided on their own participation and thus most were motivated to tell me about their experiences. Their motivation to participate was, for example, the need to talk about their childbirth experience, the possible interest of other mothers in hearing about their experience, or a sense of duty to participate in scientific research. I interviewed these women several times between 1993 and 1997. ${ }^{2}$

I define the birth experience as a personal experience narrative where the experiences are narrated in the first person singular form. Personal experience stories are also dramatic and truth-based (Stahl 1977: 20; Koskinen-Koivisto 2013: 29). In this paper, I use a broad definition of the concept of narrative, meaning the narrative consists of retold events; it has an internal structure and includes some kind of peak (Labov 1972; Adelswärd 1992). The story includes causes and consequences and involves evaluation. At the same time, narration is a form of self-representation: it is used to present oneself. It is a perception of experiences in which the interaction of form and meaning is central. This means that how something is told is as interesting as what is expressed (Nylund Skog 2002: 17). It is also a way of presenting "the way things seem to us" (Herman 2009: 145). These elements are also found in childbirth stories. They consist of experienced events with clear cause-and-effect relationships and a problem to be solved. The narrative reflects the values and norms associated with childbirth, but at the same time the way that the mother values and evaluates events.

Although I use a broad definition of narrative, I want to separate childbirth narratives into their own group. They are very consistent narratives with a precise beginning and end. The material was formed in the interview situation in response to my prompt to "tell me how your birth went, from start to finish". Some women presented their experiences relatively briefly and referentially within minutes. Others outlined their experiences as long, detailed, very cohesive stories lasting 15 to 30 minutes. I analyse the narrative formula that includes the moment of birth as well as the stylistic means of constructing a narrative that culminates in the telling of the actual birth. In addition, I analyse the experiential dimension of the story, in which the evaluation of the experience is central. So, my article is built around two key themes - the perception of the moment of birth and the experiential dimension of childbirth. First, I will briefly provide a background for birth stories as a genre and childbirth in the $1990 \mathrm{~s}$, the time of my research. 


\section{BACKGROUND TO BIRTH STORIES}

\section{Birth stories as a genre}

Childbirth has been described in different ways at different times. The most famous birth story in Christian culture is probably the Christmas gospel description of the birth of Jesus. There are tales and stories about birth. Various thoughts about pregnancy and childbirth have also developed into beliefs. These include, for example, perceptions of how the gender, appearance and characteristics of a future child could be affected in different ways, or which actions should be taken to facilitate childbirth (Tillhagen 1983, 1985; Koivu 1982; Wessman 1952).

Contemporary stories, in turn, can tell how a woman cracks from navel to lumbar spine because, contrary to better knowledge, she has called for natural childbirth (Klintberg 1986: 138). There are plenty of descriptions of childbirth in fiction, and in scenes in movies and TV series. In older films, birth takes place behind locked doors, while in contemporary filming the viewer is involved in the course of events. Childbirth stories of public figures are available in women's magazines, and tabloids report on the complications of childbirth that are supposed to be of wider interest. In addition, the medical and popular scientific literature on childbirth has, from time to time, published an obstetric birth report. Nowadays, it is common to publish your own birth story on the Internet.

What has been considered an inappropriate topic and what has been acceptable has varied over time, place, and situation. Talking about childbirth was still a matter of privacy and taboo in Finnish society in the 1940s and 1950s. Both pregnancy and childbirth were topics that were not mentioned but were silently ignored (Wrede 1998: 113). The silence was due to the fact that pregnancy and childbirth were considered shameful and also as a dangerous situation and therefore pregnancy had to be hidden for as long as possible. This silence led to ignorance. There was no talk about pregnancy and childbirth, but children were perceived to be a natural consequence of marriage (Marander-Eklund 2014: 82). Historian Yvonne Hirdman writes about the double silence associated with a woman's bodily functions, which "echoes the silence in which these women grew up and in what they carry forward" (Hirdman \& Bohman \& Rörslett 1995: 48). Hirdman interprets the silence as being based on shame about femininity and a sense of worthlessness. However, silence at the same time reflects the secret pride of femininity. According to Hirdman, the weakening of the taboo was influenced by sex education at school and awareness-raising campaigns in Sweden beginning in the 1930s (Hirdman \& Bohman \& Rörslett 1995: 49). 
Ethnologist Hilkka Helsti has estimated that this taboo disappeared in Finland when women got used to talking about pregnancy and childbirth while visiting a maternity clinic (Helsti 1995: 150). The changed attitude towards birth-related taboos can be seen in the life stories of women of different ages. Taboos and shyness no longer prevent women from talking about childbirth, probably due to the influence of the media and popular psychology (Mattsson 1998: 165). Childbirth is no longer considered a particularly private matter. Overall, attitudes towards sexuality have generally become more permissive. Society has changed at the same time as the private sphere of life has democratised; both bodily and sexual issues are discussed more openly (Giddens 1995). Sociologist Kristin Mattsson (1998), who used life history material as a starting point, has stated that younger women have patterns and linguistic means of talking about childbirth. Corporeality is strongly present in their narratives. Talking about childbirth has become legitimate and a daily routine for new mothers. Since the $1990 \mathrm{~s}$, midwives have discussed childbirth with every expectant mother, going through the course of events based on medical record. The purpose of the conversation is to help the woman adjust to her role as a mother and reduce her feelings of helplessness (Kivivirta et al. 1994: 19).

\section{Childbirth in the 1990s Finland}

In 1995, more than 60,000 children were born in Finland, which was considerably less than in the previous year. The average age of first-time mothers rose. In 1995, it was 27.8 years (Gissler \& Toukomaa \& Virtanen 1996: 2). The reason for the decline in birth rates is seen to be related to lifestyle rather than economic factors (Salmi 1994: 67). Childbirth is a physiological, bodily event, but the perceptions and norms associated with it have been very different at different times and in different societies. Perceptions of a natural and normal childbirth have varied (e.g. Oakley 1993: 124). The mother's perceptions and expectations of the upcoming event are greatly influenced by the information she has received from the media, expert literature, coaching courses, and other people's stories (Nylund Skog 1998).

In addition to perceptions, the conditions of childbirth and the persons assisting have varied. The presence of the becoming fathers during preparation and childbirth has been quite common in Finland since the 1970s (Jordan 1993 [1978]; Öberg 1996). The debate in society about childbirth gained momentum in the early 1970s, at the same time as other women's issues were being discussed (Nätkin 1997). Since the early 1980s, proponents of natural childbirth 
have been part of this debate, emphasizing the experiential side of childbirth (Odent 1986).

In 1944, statutory municipal maternity counselling was initiated, which meant investing in preventive care and counselling during pregnancy (Hänninen 1965: 234; Schoultz-Ekblad 1988: 44). Today, maternity clinics run courses to prepare parents for childbirth. In the 1990s, the courses emphasized the psychoprophylactic method, which aimed at the active participation of both mother and father in childbirth. The guide under the heading We are expecting $a$ baby, distributed to all future parents, highlighted childbirth as a natural event. It was also emphasized that families can express their wishes about the postpartum position and the time of treatment. Home birth was not recommended because it was considered to involve risks (Vi väntar barn 1995, 1997). The maternity field of the 1990s was characterized by a discussion of natural childbirth (Fjell et al. 1998). The ideas of natural childbirth with its right to self-determination were raised by, among others, the Active Childbirth Association (Klemettilä 1996: 28).

Attitudes towards pain and pain relief during childbirth have varied at different times. The debate over pain started to receive attention in the 1990s as studies showed that women feared labour pains (Suonio et al. 1993). However, at the same time, expectant mothers felt that their fear of giving birth was not taken seriously (Saresma \& Ruotsalainen 1998). In the mid-1970s, women fought for more effective pain relief, and the demand was met by increasing the number of anaesthesiologists (Hollmen \& Jouppila \& Työläjärvi 1987). Relatively quickly, the debate turned to support a more natural relationship to pain. The natural movement emphasized the positive side of pain: the pain was not pathological but active, positive, and soft - something that only women who gave birth naturally would have known (Miettinen-Jaakkola 1992: 44). Childbirth pain relief has increased rather than decreased in Finland in the 1990s, despite the fact that advocates of natural childbirth have gained a foothold (Gissler \& Toukomaa \& Virtanen 1996: 2). The review of the 1996 maternity care practice emphasized that an organic alternative should be provided instead of pharmacological relief and that the opinion of the expectant mother should be decisive. In the $1990 \mathrm{~s}$, it was popular to give birth in a semi-sitting position, on a maternity stool, or in a water bath (Salmenmaa 1998: 121). 


\section{NARRATING THE MOMENT OF BIRTH}

In women's narratives, the actual moment of birth is framed by other events that accompany childbirth. In fact, it is necessary to present the whole birth story from the beginning to the end, determined by the women themselves, in order to understand how women describe the moment of birth. Although the experiences of the interviewees are unique events, they share their experiences of childbirth in a similar way. The narratives largely follow a specific narrative pattern, to which I will return later.

I first asked my interviewees to retell the course of events. The stories begin with a depiction of the starting point situation: how, when, and where the delivery began. At this point, the women describe the events before going to the maternity hospital. Most often, they tell about their first sensations of contractions: they awoke to contractions or to the fact that their waters had broken. Narration thus begins with bodily reactions in which the mother is the central actor. Time and place are important at this point - mothers tell you where they were when the contractions started and how often they came. These events are included in a narrative that is evaluative, argumentative, and explanatory in nature. This preliminary section was included in the descriptions of most women. The decision to go to a maternity hospital is often justified by the time between contractions. Judith, who expresses herself relatively briefly, begins by saying:

Hhmm... It is said that it all started exactly like that, according to the book, so that everything happened exactly as it should. It was a few days before so I had pre-contractions, a few hours it hurt a bit and I knew that yeah, now it's starting, and then it started at night, the real pains started. (IF mgt 1995/102)

Judith assesses events, including the pain of contractions. She refers to the "book", that is, the professional literature in the field. When narrating, she compares her own experience with the normal picture of a childbirth presented in literature. In those stories where this section does not exist, the course of events has been different due to, for example, caesarean section or inducement of labour.

The stories continue with transitional events describing the arrival at the maternity hospital, which is often depicted in great detail. Central to the story at this stage is the decision to leave home and the reception at the maternity ward. There is the reception at the ward and the decision on whether the mother can stay there. The midwife acts as some kind of border guard who decides who is asked to stay and who is advised to come back later (Fjell 1998). The stories 
show that this is a matter of consultation between the expectant mother and the maternity hospital staff. Arguments in favour of the expectant mother are described in the story with references to bodily processes. At that point, the waters had broken, the cervix had opened sufficiently, or the contractions had continued long enough.

The stories continue with a depiction of events related to the opening phase of labour. This section is in the stories of all the women, despite the fact that the course of their births had taken different forms. They describe the pains and justify the use of pain relief. Dagmar says she "can't last any longer" and that she "can't cope with the pain" (IF mgt 1994/63). The pain is perceived as severe and an overall evaluation of the situation is given. It is about experiencing or avoiding pain and managing the situation and the body's reactions. Narrators describe worry and fear. At this stage, other procedures arise for the women, such as, for example, an infusion of oxytocin used to accelerate or initiate labour.

This is the longest part of the story. Similarly, the opening phase is described in the obstetric literature as the longest stage of labour, normally 8-12 hours for a first child (Saarikoski 1994 [1992]: 123). The long and gruelling physical labour of the opening phase is reflected in the stories of the mothers. Emilia felt the delivery had stopped. She tells about it with impatient and disappointed feelings and says:

And the next morning when they checked again how much it had opened, it was still that one centimetre ... And it was a disappointment that nothing really happened [laughter] even though there were pains that I started to feel pretty much like... disgusted then already. (IF mgt 1994/66)

Going forward, the woman narrates on the events related to the effort phase of childbirth. These events are given less space in the stories than the events of the opening phase. According to the obstetric literature, the effort phase in a first-time mother takes about an hour, including birth (Saarikoski 1994 [1992]: 131). The women I interviewed retell in which position the birth took place: sitting on a stool, in a semi-sitting position, or lying on the maternity bed. They narrate on what measures the staff thought were necessary to ease the birth. The effort phase is the active phase in the course of childbirth, which is also reflected in the stories. There is rarely any surrender or impatience in these parts of the accounts. In this section, too, talking about pain does not come to the fore.

From an obstetrics point of view, the effort phase is the most dramatic phase of labour, in which progress can in some cases be hindered for various reasons and the situation can become threatening (Saarikoski 1994 [1992]: 155). There is nothing in the women's stories to suggest a fear of complications. I do not 
think that means they were not afraid of complications for themselves or the child. Detailed and systematic reporting of childbirth is, in my view, one way to manage fear and keep it under control. In addition, the women knew the outcome when they spoke about it - everything had gone well. Only a few of them, according to their own assessment, were at risk. It is at this point in the story that there is no room for fear. This can be explained by the fact that the narrative in this section focuses on the actual emergence of the child, and there is simply too much happening to depict. Verbalizing fear is also not easy, and it is especially difficult in an interview situation where personal experiences are being told to a stranger.

The events described continue to lead to the goal of the whole story, the birth of a child, which most women describe. In this respect, Emilia's story is an exception. She does not really say that the child will be born at any point, but she describes the effort phase, evaluates it, and then moves on to evaluating her own experience. Judith outlines the experience of the birth herself by saying what time the baby arrived: "But so the girl was born then, at twenty to four in the afternoon" (IF mgt 1995/102). Nanny, in turn, concludes her story briefly and succinctly: "And then the boy was born... [sighs]... ten past one. And then... then it was over [laughter]" (IF mgt 1996/23). The quote shows that birth marks the end and, in this case, the end of a congruent narrative.

Only a few of the stories end as described above. Most women continue on their own without my prompting by evaluating events and telling about the encounter with their newborn child or what happened after birth. Women describe how they and the new fathers reacted to the newborn child and how they discovered the sex of the child. Women mention the weight and length of the child or describe the general condition of the child. The events are depicted with much use of evaluation. Sometimes women describe how it felt to hold their newborn baby; for example, Dagmar says:

I got the girl as soon as she had come out, so I got to keep her under my shirt for a little while, but not so that she would have started eating or something. She had me for a little while and then they sucked the mucus from her. (IF mgt 1994/63)

Postpartum events are usually included in women's stories. The women describe how the umbilical cord was cut, the wounds were sutured, and how the child was washed and weighed. This section also describes how the mother tidied herself up, took a shower, ate or called her parents, and told the big news. These events are also being evaluated.

In many accounts, the events depicting meeting the child and the aftermath constitute an ending. The women report how they were transferred from the 
maternity ward to the neonatal ward or evaluate the birth as a whole. This part could range from a few sentences to a rather lengthy statement about feelings. It constitutes the end of the story where no new events are addressed. Rather, it is a question of finalizing what has already been said or of concluding the story and returning the listener to the present, the interview situation. Here's how Flora concludes:

That's how it was then, so for me [sighing] it was a really great experience in every way. That I don't have much like ... those pains belonged there, but it was positive, seriously. That's how it went then. (IF mgt 1995/32)

Flora's concluding comment also shows that she reached the end of her story. The events described and the events forming the plot have a strong connection with the physiological course of childbirth.

\section{Birth narrative events}

The analysis described above shows that the events of the narratives can be divided into parts. The introductory part of the beginning of childbirth stories deals with the events before a woman leaves for the maternity ward and the reasons for the decision to leave. This part is characterized by a certain drama - women narrate the beginning of childbirth with varying emotions. The second recurring part deals with departure and arrival at the maternity hospital. This part is transitional in nature and is not described particularly dramatically. The third part describes the events of the opening phase in the maternity ward. Here the drama grows and intensifies in the fourth part, the effort phase. The events of this stage move the story towards the culmination, the goal of the whole story, the birth of a child. In the stories, the cause is the progressive birth and the birth of the child as a result.

Although birth is the culmination of the story, it is retold in most women's stories almost in passing. The birth itself, the fifth part, becomes an anti-climax and there is no drama involved in describing it, although the narrative always aims at it as a result of the afflictions experienced by the mother. Most continue their story even after this with a section dealing with meeting the child immediately after birth (part six). However, this is not as clear as, for example, the section on dilation. The events are hardly dramatized, but the narrative is mainly descriptive and evaluative. The part describing the meeting of the child alternates with the part describing postpartum labour (part seven). This often includes evaluative materials. The last, eighth recurring section includes a transition to the neonatal ward or an indication that the individual story is complete. 
The eight parts I found in the narratives fit very well with the narrative structure of both the obstetric literature and the complete narrative presented by linguist William Labov (1972: 363). The complete story consists of parts that include an abstract, orientation, complicating actions, evaluation, resolution, and coda. The abstract consists of a summary of the story and invites the audience to listen. The orientation presents the actors, place, time, and situation of the events. This is the part of my material that describes the beginning of childbirth. The complicating actions part describes what is essential to be told: events or problems (Arvidsson 1999). This creates a tension that then finds a solution either as an explanation for what happened or as information about how the problem was solved. The complicating actions part continues in women's stories until the end of the effort phase of labour. The evaluation is partly placed along the course of the story; partly it is placed in the report after birth. Birth corresponds to the resolution, but this also includes meeting the child and other postpartum events. The last part of the story, coda, corresponds to the final comments of the narrative.

My intention is not to examine whether the birth stories follow Labov's narrative structure, but to show that they largely follow the narrative pattern of personal experiences. In addition, I show that there is a tension in the stories between cause and effect and problem and resolution. The problem is the body working to give birth, and the solution is the birth of a child.

\section{Dramatization of birth: Stylistic means of narration}

Why does the narration of the birth itself become a narrative anti-climax? This becomes clear when examining by what kind of narrative means the story is constructed. In building up an anticipation and excitement in the narration, the women I interviewed used dramatic means: for example, strong adjectives, repetitions, laughter, sighs, irony, emphasis, and direct quotation (MaranderEklund 2002: 113). These dramatizing means are being used more and more effectively the closer we get to the climax of events and of the narrative, i.e. birth. It is often a matter of intolerable pain, general fatigue, or fear of losing control. Flora represents those who feel the urge to give up. She says, "So I thought now [laughter], if it doesn't come out now, then I'll give up [laughter]. She was hugely good, that midwife, and she said to me a little more. She encouraged me very much" (IF mgt 1995/32). Flora laughs embarrassingly at her desire to give up. At the same time, the quote shows the importance of the midwife's support. In a separate article on the importance of laughter in childbirth stories, my research shows that women resort to laughter when dealing with difficult 
physical matters. Laughter is used to explain, apologize, smooth, increase or decrease drama, underline or mark things (Marander-Eklund 2008).

Anita underwent a planned caesarean section. She describes how the anaesthesia began to affect her and how the surgeon came in. In addition, she evaluates the feelings of concern and fear that she felt during the operation. She goes on to recount the birth itself, mentioning its duration: "But it went awfully fast, it was about five minutes and so they took the boy out" (IF mgt 1993/22). She then moves on to judging the experience itself: how wonderful it was to see the child lifted out of her belly. Benita also describes the birth of a child with a precise expression of time: "But so that after an hour and $57 \mathrm{~min}$ utes [laughter] the boy then was born. And it was so weird [whispers] when he came out." Benita then goes straight to assessing what happened. She states that she forgot to tell how her waters broke at an earlier stage of events and how she was amazed that "it was such QUANTITIES [loud and emphatic]. It flowed [emphatically] out of me" (IF mgt 1994/60). Benita jumps back in time to explain and clarify what happened. This shows that Labov's narrative formula is only the starting point for narration. Because women know how the birth story should proceed, they can easily make deviations from the structure of the story without breaking it down. After the deviation, Benita returns to events after birth, and as a listener I have no difficulty following.

Hagar dramatized her story by repeating word for word what those present were talking about. She describes a conversation involving her husband, a midwife, a doctor, and herself. All mothers, except one had company of their husbands or partners in the birth situation, but the becoming father is quite absent in the stories. Usually, when interviewing others, the interviewees do not translate the midwives' speech from Finnish into Swedish, even though the story was otherwise produced in Swedish. For example, Hagar puts it: "It goes well" [in Finnish], while the man's encouragement is in Swedish: "Jo, jo, det går bra, det här går ju riktigt strålande" (Yes, yes, it goes well, it goes quite brilliant). The same goes for the doctor's comment on Hagar's way of giving birth: "Oh, it likes to give birth like that" (IF mgt 1995/77). The use of the pronoun "it" shows that the doctor talks to the midwife and ignores Hagar in the situation.

Carita, for her part, narrates the birth itself dramatically because it was difficult for the baby to fit through and the midwives and doctors threatened to take a suction cup. She says:

And when we then decided to take it [suction cup], then there really came a lot of doctors. It was almost unpleasant because like all those people rolled in and then I lay down and felt that, yeah, what was happening now. Then came another midwife who jumped on my belly and one 
doctor, a gynaecologist, one paediatrician and one nurse. As they want to immediately check that it has gone well, the suction cup. (IF mgt 1994/55)

In her story, Carita dramatizes the events using strong words like "unpleasant" and explains how doctors rolled in and how the midwife jumped on her stomach. The birth itself she narrates as follows:

That's when I was not quite there and I yelled pretty much [laughter]. And so, and ... but then the boy finally arrives. They said he had then come easily with a suction cup, after all it was almost that he didn't fit. (IF mgt 1994/55)

Birth is described in few words and without drama ("but then he finally arrived"), while the situation just before birth is told very dramatically. The statement "he almost didn't fit" means that the next procedure would have been a caesarean section. The situation was thus "almost" a caesarean section. Dramatizing the experience with such "almost" events also occurs in the stories of other women: there was an "almost" suction cup, they "almost" gave birth to a toilet bowl, or "almost" fainted in the shower. These "almost" narratives are so-called close call stories and contain a clear tension between the complicating action and the subsequent resolution (Labov 2013: 226). In that respect, they are very similar to the narratives on which Labov developed the breakdown of the basic structure of the narrative. In Harlem, he studied stories based on young boys' own experiences. They dealt with the boys' lives on the streets of Harlem and described a relatively dangerous life that included violence and situations that could have gone badly. There are also situations in birth stories I researched that could have gone very badly. These parts can be seen as a way to dramatize events, but also as a way to show the listener that giving birth is hard work.

Emilia narrates about the effort phase and birth, and then goes on to tell about the sex of the child anecdotally:

And then I got to start straining him out but then I didn't have such severe labour pains yet, so I got that kind of... snuff [hormone in snuff form]. And that stage wasn't as painful for me. Maybe because you knew it was about to pass or hoped [laughs] at least that it would go faster in the end. Then when it was when the child had really arrived and I heard him scream and didn't see him, it felt pretty awful, I gave birth on all fours, so my husband, who was involved, said "guess, guess what?" [laughing] So, then I, I remember, became wildly angry, "Well, say now whether a girl or a boy has arrived" [laughing] or at least I thought, yes, I did say something angry [sighing]. (IF mgt 1995/73) 
The effort phase and the associated impatience that the situation is not progressing faster are described above. Emilia laughs as she says she hoped the birth would go faster. Birth is not really verbalized other than "when the child had actually arrived". Instead, a dialogue between Emilia and her husband on the gender of the child is described, with dramatizing elements such as sighing and direct quotes. Also, in the other women's stories you can find the transition from birth to dealing with the sex of the child. In her story, Carita explains the midwife's words, "So she took my hand and put her hand between Carl's [child's] legs and said, 'Look what kind of football player you've got now' [laughing]" (IF mgt 1995/45). Ingegärd, for her part, asks the midwife for the sex: “Which is it?' - 'I can't say yet,' said the midwife" (IF mgt 1995/80). The use of direct quotation results in women changing the tense in their narration and using the so-called historical present in a context where the imperfect is otherwise prevalent.

The women have been expecting to give birth and have prepared for childbirth. Yet they are almost amazed that the result is a child. Flora describes how the midwife asked her to feel her child's head in the effort phase: "So I felt a small soft slimy lump [laughing]. I thought, is this a small human head?" (IF mgt 1995/32) Flora is almost amazed that she really gives birth to a human. This astonishment is shared by many others, indicating that they are prepared primarily for childbirth and not for the birth of a child. The focus is thus more on action and process than on the outcome of childbirth. Gudrun's surprise is related to the child's appearance:

And then the midwife said now it shows its head and it has black hair... And then I remember that I went just like, WHAT? ... it was all wrong [a little laughing] but I hadn't had any picture of that baby, but I was still thinking of a three kilo bald baby, even though I hadn't thought of any facial features, or something... who it would resemble. But that was completely wrong, a big black-haired baby. (IF mgt 1995/75)

Women tell about birth by dramatizing the events around the birth itself. These include the pain of the opening phase, the slow progress of the birth in their opinion, and the hard work of the effort phase. The birth itself is presented in few words and relatively undramatically. Most often women just say what time it was when the child was born. It feels like the birth-givers do not really have any more to tell. Instead, it describes events related to the child - for example, the amazement that the child was born - as well as telling the child's gender and describing their appearance. The actual birth of a child into the world is seen as the result of hard physical labour. It is a relief for the mother if no complications have occurred. The moment of birth is also over relatively 
quickly. It is therefore logical that the story focuses on the child, its gender and appearance, or what it felt like when the child was born.

Childbirth manuals, counselling, and stories from other women do not provide narrative models for the narration of the moment a child is born, as the steps that precede this require more attention. The fact that the moment of birth is described only in few words does not diminish its significance, but rather shows how important the evaluation of events is for women. This is related to the individual experiential dimension of childbirth, which I address below.

\section{BIRTHGIVING AS EXPERIENCE}

\section{Individual experience and shared experiential knowledge}

The analysis of personal narration raises questions about the relationship between the concepts of individual experience (Erlebnis) and shared experiential knowledge (Erfahrung) (cf. Hovi 2007: 22). Individual experience means that a person is involved in an event, while experiential knowledge means awareness and knowledge contained in the experience. Experiential knowledge also includes individual experiences (O'Dell 2002: 20). I use the concept of individual experience as an interpretation of an event in which the interviewee has been involved and which has a beginning and an end. Meanings and expressions are given to this individual experience through linguistic means (Svalastog 1998: 29).

In the interviews, the mothers talk about their individual childbirth experience and interpret this event while expressing it in words. Individual experience, in turn, leads to experiential knowledge. The empty shell of the narrative is filled with individual, embodied experience and an evaluation of the events that are included in the experience and that form the starting point for the personal narrative. Evaluating and assessing an individual's experience highlights the narrator's perspective on the experience, demonstrates attitudes towards what happened, and expresses emotions (Labov 1972; Adelswärd 1996).

As I have already mentioned, the women I interviewed were specially prepared for the experience of childbirth. They had prepared, among other things, by reading the relevant literature and had high expectations specifically for childbirth. In their accounts, they compare their expectations with their experience. In some cases, expectations fit well with the experience, but some women also say that everything went differently than they had thought. The stories express expectations in different ways: "as I had thought", "as I had expected", "I thought", and "I had planned". Expectations and their fulfilment 
are also expressed more precisely if something during childbirth, such as pain, was "much harder ... than I could have ever imagined" (IF mgt 1995/32). Unfulfilled expectations are described by phrases like "so it didn't go exactly as planned" (IF mgt 1995/135). This could relate to the whole course of childbirth or to some individual procedure or event that the mother had hoped to avoid. Expectations may relate to the course of events in general, so that the mother can control both herself and the whole situation. Women also talk about their expectations about the hospital, such as the place of delivery and the quality of the pain, the fear of the need for premature effort, the desire to avoid epidural anaesthesia, but also the anticipation of the child and his or her appearance.

Supported by these expectations, the mothers built their story based on a plan of what the course of the birth should be like. Creating a more or less conscious plan was part of mental preparation for childbirth. Expectations show that there is an intertextual relationship between texts and ideas about childbirth (cf. Honko 1998: 33). In the birth story, the outline or mental text of this plan appears as the expectations described by the narrators. Expectations form the starting point or formula by which women narrate, although this is not uttered aloud.

A plan based on pre-conceptions would have allowed women to narrate childbirth-related events even before they had gone through their individual experiences. However, they could not have told in advance how they experienced childbirth or what it was like to become a mother. The dimension of the story's individual experience shows that they had positive expectations for childbirth. That is why they narrate events as birth-givers and not as new mothers. They were confused by the result of childbirth: the fact that they had a child. At some level, this became, of course, clear to them, but their preparation had not focused on the child but on childbirth. I can only make assumptions about why this is like that. Perhaps one reason is the notion of childbirth as a revolutionary peak experience that prevailed in the 1990 s and is still likely to prevail. The concept of peak experience was created by psychologist Abraham Maslow. It has been used to show positive events that fundamentally change an individual's way of perceiving themselves (Petri \& Cofer n.d.). There are strong positive emotions associated with peak experience. Such is the case, for example, with the feeling that extreme athletes experience after a demanding performance (Lassila 2007: 77). Thus, giving birth becomes an experience comparable to extreme sports. At the same time, the human need to be a unique individual and to invest in one's own life is satisfied (Bauman 2001: 172). 


\section{A fantastic or confusing experience?}

The women evaluated individual events throughout the story. In addition, half of the women present in their story a unified spontaneous assessment of their entire childbirth experience. In many cases, the assessment is at the end of the story, after the description of the birth itself. Evaluation is a reflection of the whole course of events with the starting point as the self, its understanding of the course of childbirth and its own contribution to it. As in Judith's story, in many cases a significant part of the end of the story is the evaluation of the experience presented by the mother. Judith describes the birth and then voluntarily evaluates both a few events and the experience as a whole:

And so the girl was born, at twenty to four in the afternoon. So, it didn't take an awful long time. So, that's how the course of events was, the course like how it went. And in my mind you react to it somehow, as you thought it would react, so that when you're in the middle of it, I didn't think so much that I did keep my head pretty cool [laughing] so that I could act even though it hurt, it did hurt. But that ... but then there were other things that could be forgotten that had just been imagined [laughing] about childbirth positions and more. It was like a secondary thing [in Finnish]. Then when you're in it ... That you can't then, I felt afterwards, then it feels like you couldn't imagine ... at all that yeah, yeah so I want to give birth hanging from a curtain rod [laughing] that it, it... Then there are other things that are more important, at least for me ... So that, so that it was now then a brief summary. (IF mgt 1995/102)

Above, Judith connects to her previous expectations of the duration of childbirth and her own reactions to pain and childbirth as a whole. For her, expectations were partly met and partly unfulfilled. Flora evaluates childbirth twice, and the latter evaluation concludes in the form of an elegant final summary:

But to be a first-time mother so it probably went terribly well, as if it was right... ideal childbirth, no complications or nothing like that ... So it was like that, so for me [sigh] it was kind of wild, such a great experience in every way. That I didn't have much like... those pains were of course one thing that was involved, but that it was yes indeed positive. That so-so it went. (IF mgt 1995/32)

Based on her pains, Flora estimated that hers had been an ideal birth. Dagmar, on the other hand, represents those who do not give a clear overall evaluation in their story. However, she explains her feeling of surrender during childbirth. 
Hagar's account is very reflective, and she ponders deeply about her role in an active childbirth. Certain women, such as Marta, did not evaluate their experience voluntarily, but did so only when I had specifically asked about it.

In their evaluations, women highlight different aspects of the experience. Ingegärd evaluates her experience spontaneously and positively: "So that, I don't know, I have a hugely positive experience of it all. That it was not ... I have never had such an idea of what I have begun, no, I won't do that again" (IF mgt 1995/80).

Emilia's assessment of the experience focuses on the duration of childbirth, which in her own perception took a long time. Konstance commented at the end of her story on the enormous fatigue she felt after the birth of the child. The experience of meeting the newborn child also appears in the assessments of some women. Among other things, Gudrun talks about how she felt the child really was a stranger. She compares the experience of giving birth to other great experiences of her life and proudly says about her performance in giving birth to a child:

It felt like... when there's something left behind when you've done something big. A bit the same feeling as when I received the school graduation certificate, an ever so solemn occasion, so now that I have achieved something, and just at that moment ever so happy. (IF mgt 1995/75)

Gudrun says she did not live through a "nirvana experience" that she had heard other women talk about. She also refers to her own mother's experience of childbirth and her ability to hold the reins in her hands during childbirth. Gudrun combines the expectations she has gained from other women's experiences and knowledge with her own assessment of her experience. Hagar also attaches to her assessment her expectations, especially her desire to be able to give birth actively and naturally. She estimates that she had thought it more difficult to have a child than she had experienced in the end. Stories often state that women are satisfied that they had "survived" childbirth. In these cases, the individual experiential dimension is on the surface, and women share their experiences as birth-givers rather than new mothers.

An emotional examination of childbirth is reflected, for example, in the assessment of pain. The experience is often seen as positive and joy-filled, but expressions of fear and confusion are also used. Anita says she was "happy, fearful of death and full of horror" (IF mgt 1993/22). Dagmar stands out from my interviewees because she expresses strong emotions when evaluating events. She says: 
I thought I couldn't stand it anymore, as if I wouldn't make it [almost crying], I didn't think at all that I had a child to give birth to, I just thought that, well now I'm about to die [laughing]. (IF mgt 1994/63)

Dagmar uses the Swedish term stryka med (perish), which can be thought of as a euphemism for death. At the same time, the quote again shows how childbirth is dominant and perceived as burdensome, and that the child remains secondary at this stage. Fear also emerges in contexts where women felt they did not control the situation they described. A good example of this is the previous quote from Dagmar's account, which uses soothing laughter.

In assessing the whole birth, Dagmar refers to another place and another time, the mythical time "before". She compares her own ability to women "who have given birth at home and who gave birth before and such" (IF mgt 1994/63). Gudrun also reflected on her situation by comparing it to a historical time, the beginning of the twentieth century, when women gave birth without medical technology. She is horrified by what would have happened then to her child, who was almost pulled out and whose clavicle broke as a result. This shocked Gudrun: "When I still think about it I am a little scared when I think that if I hadn't been giving birth in the twentieth century, how would I have done 100 years ago?" (IF mgt 1996/44)

The quotations above express the concern or fear that women felt about the situation and this is related to the perception of a "primitive" woman who gave birth without much effort. Folklorist Susanne Nylund Skog (2002: 63) presents the notion of a "mother giving birth in the middle of potato harvest", a woman who works in a field at harvest and unnoticed deviates from her job to give birth to a child. This perception, according to Nylund Skog, was still valid in the Scandinavian context in the 1990s. Despite high-tech hospitalization - or perhaps due to its impact - women compare their own ability to give birth to a mythical era, the "birth myths" they know, and exemplary narratives.

The examination of women's birth experiences shows in how many ways they evaluate and view the experience in the form of a narrative. Evaluation is one way to fill a story with meanings. Some women have a single evaluative section at the end of the story, while others have more fragmented comments. Relatively few women directly say the experience was good or bad. Some emphasize that childbirth was a fantastic experience, while others view it with mixed feelings. How big a part of the experiential dimension of childbirth in women's stories depends on women's attitudes toward childbirth? Those who hope for a normal birth focus on having a child and do not experience childbirth as a great experience. In contrast, those women who plan their childbirth in detail and become familiar with the literature in the field have strong opinions 
about how childbirth should go. They also have high expectations of the experiential dimension of childbirth, which is also reflected in their accounts. For these women, the experiential nature of childbirth is central.

Above, I showed that narration is largely form-bound, although women's experiences of childbearing differ and are largely unique. The narrative pattern can be seen in the narratives of all women, yet there are significant differences in the narrator's personality, in the amount of detail, dramatization, explanation, or how entertainingly they tell their stories in different types of interview situations. The story becomes the woman's own one, based on what kind of evaluation she makes, how she dramatizes events, and what message she wants to convey in her story. Finally, I consider the meanings of the birth story, its idea, and the meanings of experience and telling.

\section{CONCLUSION: POINTS OF EXPERIENCE AND NARRATIVE}

I have demonstrated above how evaluation expresses the narrator's perspective on experience, which shows their attitudes and creates ways to express their emotions. With this evaluation, the narrator emphasizes the point of the story. Laughter, the use of direct quotes, and anecdotes also denote the point of the story (Bauman 1986; Kaivola-Bregenhøj 1988). But what does the story deal with on a deeper level? What message does the first-time birth-giver transmit in her account of childbirth, obstetric care, and herself as a birth-giver?

The key message in these narratives is that new mothers show that they have survived the giving birth to a child. Childbirth may have been perceived as more difficult or easier than expected, but they still managed to do it. It is an accomplishment that mothers tell about with joy and pride. In their stories, women address the experience and describe it in a consistent format, emphasizing their own action. They tell about themselves as birth-givers who have endured childbirth and thus become part of the maternal community. Their stories deal with women's identities as women, birth-givers, and new mothers.

The experience of giving birth is central to the story. Even those women whose experience was not ideal unexpectedly share their experiences, building a happy-end version. They can deal with this story and live with it. They turn a negative event into a positive one as if to correct what happened (Lehmann 1978). The stories deal with the birth self, which strengthens identity as both a woman and a birth-giver. They also create a part of the life story.

In general, the providers of my material were satisfied with the obstetric care received. It was essentially adapted according to the wishes of the mother 
to natural or conventional childbirth. However, the stories involve tacit criticism of the hospital. This comes to the fore when women talk about weak autonomy and helplessness in the hospital machinery, the difficulty of getting their wishes forward, and the reluctance of the hospital staff to fulfil their aspirations. The feeling of being at the mercy of others also contributed to the fact that the woman might not have wanted or dared to express her wishes. The birth-giver was at a disadvantage in relation to the trained staff. The stories also address the fact that high expectations were not met and that the women felt tortured, suffered, and were insecure about both the course of childbirth and their own role in it. Confused laughter shows that pain and other bodily reactions were central parts of the experience. At the transition level, there is also existential fear in the narratives. However, the message of the stories is also the happiness experienced since the birth of the child, which the women expressed enthusiastically and proudly.

Those women whose births went as expected presented hero stories. In them, proudly and dramatically using, among other things, a laugh-reinforcing element, they talked about things that "almost" happened - but in the end everything went tremendously well. The experiential dimension is strong in the narrative and puts the actual birth-giver at the centre. Birth becomes the culmination of the story. This is reflected in the fact that postnatal events are described in a temporal and local vacuum, and they form the anti-climax of the narrative rather than its climax. The story deals more with childbirth than with the birth of a child. Psychologically oriented researchers emphasize that a mother may not feel like a mother when she is still giving birth. Rather, it is a matter of process, and the woman who has given birth to a child gradually becomes a mother (Stern 1999). Women have high expectations, and childbirth as well as childbirth experience is important to them. In contrast, they are less prepared for motherhood on both an emotional and practical level. Some stories do not elicit any actual message or point. In this case, the narrative itself, the detailed description of the events, becomes the main idea.

The narrative shapes a wide range of key points. According to Viveca Adelswärd (1992, 1996), a researcher in speech communication, they have, first of all, an anecdotal point, where the idea is to tell a good story in itself. Women's stories are mostly very entertaining to listen to. This is also shown by the large amount of the narrator's amused laughter intertwined with the narrative. Often women put themselves in a comic position and thus laugh at themselves as well. Secondly, Adelswärd talks about points of embedded values. These reflect women's views of pain, corporeality, femininity, and childbirth as an embodied experience. Women's stories describe the values associated with childbirth, the movement between natural and medical childbirth. Indeed, 
women approach their births differently in their accounts. They emphasize safety and not question hospitalization but do give both praise and reproaches to obstetric care. The stories also reflect women's relationship to their bodies. They are stories of power, control, intuition, and knowledge. They highlight the norms of Finland's ideal birth in the 1990s, where naturalness is at one end of the scale and the possibility of choosing interventions at the other. The story illustrates how giving birth to a child is seen as part of the formation of femininity and sex-related values. Women talk about these things ironically, critically, and bitterly but also with humour, enthusiasm, and pride.

Thirdly, the narratives describe the narrator's goal to create coherence in the narrative. Women narrate childbirth both as birth-givers and as women. There are norms associated with both childbirth and femininity. The notion of a "proper" childbirth is on the line between refusing medical intervention on the one hand and avoiding suffering on the other. Women talk about childbirth as performance: you must be determined and cope with childbirth, which for some means coping without pain relief and for others coping with childbirth as such. The narrator can depict a difficult experience with self-pity. In their stories, however, most women translate their experiences into one that they not only survived but coped well with. At the same time, the birth itself remains in the story a matter that is depicted in a few words and no emotions at all: "but then the boy finally arrived".

\section{NOTES}

1 I conducted the interviews myself and, while gathering this material, ethical questions were especially important to me. Maintaining the anonymity of the interviewees was vital, and no one can be identified from the interviews. I made a contract with each woman to use the interviews. I have examined my interview material in my doctoral thesis in folkloristics, Berättelser om barnafödande: Form, innehåll och betydelse $i$ kvinnors muntliga skildring av födsel (Marander-Eklund 2000). The main aim of the doctoral thesis was to study how first-time mothers articulate their corporeal childbirth experiences in their childbirth narratives. I kept in touch with the mothers and told them about the progress of the research. The women have had a chance to study the portraits of the mothers in my doctoral thesis and approve their contents. The material is archived in Cultura, the Åbo Akademi University Folklore Archive. This article is translated and proofread by Jorma and Maria Vatanen.

${ }^{2}$ For my doctoral thesis I conducted recurrent interviews of which the first one was made before the birth, the second one soon after the birth, and the third one a year after the birth. The aim was, on the one hand, to study women's expectations about childbirth and, on the other hand, to compare two different variants of a childbirth narrative. In this article, I am not studying the pre-conceptions nor do I compare variations with each other. Instead I focus on the stories, described soon after the 
birth. These interviews were carried out in the interviewees' homes 3-4 weeks after the child was born. During the first interview we had become acquainted with each other which had, in my opinion, a positive influence on our interaction in the second interview.

\section{ARCHIVAL SOURCES}

Turku, Åbo Akademi University, Cultura Folklore Archive: IF mgt 1993/22

IF mgt 1994/55, 60, 63, 66

IF mgt 1995/32, 45, 73, 75, 77, 80, 102, 130, 135

IF mgt 1996/1, 23, 44

\section{REFERENCES}

Adelswärd, Viveca 1992. Den första älgen. Om strukturen i en typ av narrativ. [The First Elk: About Narrative Structure.] In: Staffan Hellberg et al. (eds.) Svenskans beskrivning, Vol. 19. Lund: Lund University Press, pp. 62-72.

Adelswärd, Viveca 1996. Att förstå en berättelse: eller historien om älgen. [Understanding a Narrative - or the Story of the Elk.] Stockholm: Bromberg.

Arvidsson, Alf 1999. Folklorens former. [The Forms of Folklore.] Lund: Studentlitteratur. Available at https://www.academia.edu/34681003/Folklorens_Former_2.pdf, last accessed on 12 October 2020.

Bauman, Richard 1986. Story, Performance, and Event. Contextual Studies of Oral Narrative. Cambridge: Cambridge University Press. https://doi.org/10.1017/ CBO9780511620935.

Bauman, Zygmunt 2001. Det individualiserade samhället. [The Individualized Society.] Uddevalla: Daidalos.

Fjell, Tove Ingebjørg 1998. Fødselens gjenfødelse: Fra teknologi til natur på fødearenaen. [Rebirth of Birth: From Technology to Nature on the Birth Arena.] Kristiansand: Høyskoleforlaget.

Fjell, Tove Ingebjørg \& Hagström, Charlotte \& Marander-Eklund, Lena \& Nylund Skog, Susanne (eds.) 1998. Naturlighetens positioner: Nordiska kulturforskare om födsel och föräldraskap. [Positions of Naturalness: Scandinavian Cultural Researchers on Birth and Parenthood.] Åbo: Nordiskt nätverk för folkloristik.

Giddens, Anthony 1995. Intimitetens omvandling: Sexualitet, kärlek och erotik $i$ det moderna samhället. [The Transformation of Intimacy: Sexuality, Love and Eroticism in Modern Societies.] Nora: Nya Doxa.

Gissler, Mika \& Toukomaa, Henri \& Virtanen, Martti 1996. Perinatalstatistik 1995. [Prenatal Statistics.] Helsinki: Stakes.

Hänninen, Sisko-Liisa 1965. Kätilötyön vaiheita. [Phases in Midwifery.] Helsinki: Otava. 
Helsti, Hilkka 1995. Raskaus ja synnytys parin sukupolven takaa. [Pregnancy and Childbirth Two Generations Ago.] In: M. Sorvettula (ed.) Naisen terveys: Hyvän elämän strategiset mitat. Helsinki: Kirjayhtymä, pp. 145-178.

Herman, David 2009. Basic Elements of Narrative. New Jersey: John Wiley \& Sons.

Hirdman, Yvonne \& Bohman, Kristina \& Rörslett, Maj Birgit 1995. Påminnelser: om kvinnors liv $i$ Sverige. [Reminders: About Women's Life in Sweden.] Stockholm: Carlsson.

Hollmen, Arno \& Jouppila, Riitta \& Työläjärvi, Riitta 1987. Synnytyskivun lievityksen kehitys ja nykytila Suomessa sekä tulevaisuuden haasteet. [Developing Pain Relief during Birth in Finland.] Suomen lääkärilehti, Vol. 42, pp. 1158-1164.

Honko, Lauri 1998. Att synliggöra textualiseringsprocessen. [Making the Process of Textualisation Visible.] Tradisjon: tidsskrift for folkeminnevitskap, Vol. 1, pp. 33-41.

Hovi, Tuija 2007. Usko ja kerronta: Arkitodellisuuden narratiivinen rakentuminen uskonliikkeessä. [Belief and Narration: The Narrative Construction of Everyday Reality in the Faith Movement.] Elore, Vol. 14, No. 1, pp. 1-4. Available at https://journal.fi/elore/article/view/78636/39535, last accessed on 12 October 2020.

Jordan, Brigitte 1993 [1978]. Birth in Four Cultures. A Cross-Cultural Investigation of Childbirth in Yucatan, Holland, Sweden and the United States. Revised and expanded by Robbie Davis-Floyd. Long Grove, Illinois: Waveland Press, Inc.

Kaivola-Bregenhøj, Annikki 1988. Kertomus ja kerronta. [Narrative and Narrating.] Helsinki: Suomalaisen Kirjallisuuden Seura.

Kivivirta, Louise \& Vehviläinen-Julkunen, Katri \& Lauri, Sirkka \& Callister, Lynn Clark 1994. Eri kulttuureissa elävien naisten kokemuksia synnytyksestä ja äitiydestä. [Experiences of Birthgiving and Motherhood by Women from Different Cultures.] Turku: Turun kaupunki.

Klemettilä, Sinikka 1996. Kymmenen vuotta aktiivista synnytystä. [Ten Years of Active Birth Giving.] Vauva, No. 2, p. 28.

Klintberg, Bengt af 1986. Råttan i Pizzan: folksägner $i$ vår tid. [The Rat in the Pizza: Legends of Our Time.] Stockholm: Norstedt.

Koivu, Leena (ed.) 1982. Syntymä: Enteitä ja uskomuksia. [Birth: Omens and Superstitions.] Helsinki: Suomalaisen Kirjallisuuden Seura.

Koskinen-Koivisto, Eerika 2013. A Greasy-Skinned Worker - Gender, Class and Work in the 20th-Century Life Story of a Female Worker. Jyväskylä: University of Jyväskylä. Available at https://jyx.jyu.fi/bitstream/ handle/123456789/42505/978-951-39-5517-5_2013.pdf?sequence=1\&isAllowed=y, last accessed on 12 October 2020.

Labov, William 1972. Language in the Inner City: Studies in the Black English Vernacular. Philadelphia: University of Pennsylvania Press.

Labov, William 2013. The Language of Life and Death: The Transformation of Experience in Oral Narrative. Cambridge: Cambridge University Press.

Lassila, Janina 2007. Vår tids och vår kulturs gränstänjning - en studie om extremsportutövarens jaggestaltning. [Pushing Boundaries of Our Time and Our Culture - A Study of the Extreme Sportsman's Self-Management.] In: Anna-Maria Ånäs \& Janina Lassila \& Ann-Helen Sund \& Lotta Wessberg (eds.) Extremt? Etnologiska analyser av kvinnorock, extremsport och Ultimate Fighting. Turku: Åbo Akademi, pp. 53-182. 
Lehmann, Albrecht 1978. Erzählen eigener Erlebnisse im Alltag. Tatbestände, Situationen, Funktionen. Zeitschrift für Volkskunde, Vol. 74, No. 2, pp. 198215. Available at https://www.digi-hub.de/viewer/image/DE-11-001938277/554/ LOG_0200/, last accessed on 14 October 2020.

Marander-Eklund, Lena 2000. Berättelser om barnafödande. Form, innehåll och betydelse $i$ kvinnors muntliga skildring av födsel. [Narratives of Childbirth: The Form, Content and Meaning in Women's Oral Depiction of Birth.] Diss. (PhD Thesis). Turku: Åbo Akademis förlag.

Marander-Eklund, Lena 2002. Narrative Style: How to Dramatize a Story. Arv: Nordic Yearbook of Folklore, Vol. 58, pp. 113-123.

Marander-Eklund, Lena 2008. Narrative and Emotions: Revealing and Concealing Laughter. Folklore: Electronic Journal of Folklore, Vol. 39, pp. 95-108. http:// dx.doi.org/10.7592/FEJF2008.39.eklund.

Marander-Eklund, Lena 2014. Att vara hemma och fru: En studie av kvinnligt liv $i$ 1950-talets Finland. [Staying at Home and Being a Wife: A Study of Woman's Life in the 1950s Finland.] Helsingfors: Svenska litteratursällskapet i Finland. Available at https://www.sls.fi/sv/utgivning/att-vara-hemma-och-fru, last accessed on 14 October 2020.

Mattsson, Kristin 1998. Från värkar till sammandragningar: Olika sätt att tala om graviditet och förlossning. [From Labour Pain to Contractions: Different Ways of Talking about Pregnancy and Childbirth.] In: Harriet Silius \& Ann-Catrin Östman \& Kristin Mattsson (eds.) I dialog med kvinnoliv. Turku: Åbo Akademi, pp. $165-188$.

Miettinen-Jaakkola, Aila 1992. Nainen naiselle: Luonnollinen syntymä. [From Woman to Woman: Natural Birth.] Helsinki: Kääntöpiiri.

Nätkin, Ritva 1997. Kamppailu suomalaisesta äitiydestä: Maternalismi, väestöpolitiikka ja naisten kertomukset. [The Struggle of Finnish Motherhood: Maternalism, Population Politics and Women's Stories.] Helsinki: Gaudeamus.

Nylund Skog, Susanne 1998. Den ideala förlossningsupplevelsen: Tre kvinnors berättelser om barnafödande. [The Ideal Birthgiving Experience: Three Women's Stories about Childbirth.] In: Tove Ingebjørg Fjell \& Charlotte Hagström \& Lena Marander-Eklund \& Susanne Nylund Skog (eds.) Naturlighetens positioner. Nordiska kulturforskare om födsel och föräldraskap. Åbo: Nordiskt nätverk för folkloristik, pp. 97-114.

Nylund Skog, Susanne 2002. Ambivalenta upplevelser \& mångtydiga berättelser: En etnologisk studie av barnafödande. [Ambivalent Experiences and Ambiguous Narratives: An Ethnological Study of Childbearing.] Stockholm: Stockholms universitet.

Oakley, Ann 1993. Essays on Women, Medicine \& Health. Edinburgh: Edinburgh University Press.

Öberg, Lisa 1996. Barnmorskan och läkaren: Kompetens och konflikt $i$ svensk förlossningsvård 1870-1920. [The Midwife and the Doctor: Competence and Conflict in Swedish Childbirth Care 1870-1920.] Diss. (PhD Thesis). Stockholm: Ordfront.

O’Dell, Tom 2002. Upplevelsens lockelser, tingens dynamik. [Enticement of Experience, Dynamics of Things.] In: Tom O'Dell (ed.) Upplevelsens materialitet. Lund: Studentlitteratur, pp. 11-34. 
Odent, Michel 1986. Luonnonmukainen synnytys: onnellinen ja turvallinen menetelmä äidin ja lapsen parhaaksi. [Birth Reborn: A Happy and Safe Method for the Benefit of Mother and Child.] Jyväskylä: Gummerus.

Petri, Herbert L. \& Cofer, Charles N. n.d. Motivation. Applications in Society. Britannica. com. Available at https://www.britannica.com/topic/motivation/Applications-insociety, last accessed on 12 October 2020.

Saarikoski, Seppo 1994 [1992]. Synnytysopin perusteet. [Introduction to Obstetrics.] 2nd ed. Tampere: Legekustannus.

Salmenmaa, Virpi 1998. Synnytyksen hoitokäytäntö Suomessa. [Clinical Practice of Birthgiving in Finland.] Tidskrift för barnmorskor, No. 2, pp. 12-13.

Salmi, Lauri 1994. Perheen lapsiluvun suunnitteluun vaikuttavat tekijät: Tutkimus turkulaisista naisista. [Factors Influencing the Planned Number of Children: A Study of Turku Women.] Turku: Turun yliopisto.

Saresma, Tuija \& Ruotsalainen, Erja 1998. Synnytyspelot ovat yhä vaiettuja ja vähäteltyjä. [Fears of Birthgiving Are Still Silenced and Belittled.] Anna, Vol. 36, No. 20 , pp. 56-60.

Schoultz-Ekblad, Birgitta 1988. I livets tjänst: Ett historiskt sökande av barnmorskans paradigm under tiden 1896-1970. [In the Service of Life: A Historical Search for the Midwife's Paradigm during the Period 1896-1970.] Helsinki: Helsingfors svenska sjukvårdsinstitut.

Stahl, Sandra 1977. The Oral Personal Narrative in Its Generic Context. Fabula, Vol. 18, pp. 18-39. http://dx.doi.org/10.1515/fabl.1977.18.1.18.

Stern, Daniel N. 1999. En mor blir till: Hur moderskap förändrar dig för all framtid. [Birth of a Mother: How Motherhood Changes You Forever.] Stockholm: Natur och Kultur.

Suonio, Sakari \& Vartiainen, Heikki \& Laasanen, Tuula \& Saarikoski, Seppo 1993. Synnyttäjän yleiset ja synnytykseen liittyvät pelot. [Anxiety among Birthgivers.] Suomen Lä̈̈kärilehti, Vol. 32, pp. 3133-3138. Available at https://www.laakarilehti. fi/tieteessa/alkuperaistutkimukset/synnyttajien-yleiset-ja-synnytykseen-liittyvatpelot/, last accessed on 14 October 2020.

Svalastog, Anna Lydia 1998. Det var ikke meningen ... Om konstruksjon av kjønn ved abortingrep, et feministteoretisk bidrag. [I Didn't Know... Induced Abortion and the Process of Gender Construction, a Theoretical Feminist Contribution.] Diss. (PhD Thesis). Uppsala: Uppsala universitet.

Tillhagen, Carl-Herman 1983. Barnet $i$ folktron: tillblivelse, födelse och fostran. [The Child in Folk Belief: Creation, Birth and Education.] Stockholm: LT förlag.

Tillhagen, Carl-Herman 1985. Konsten att skaffa sig vackra barn. [The Art of Making Beautiful Children.] Stockholm: LT förlag.

Vi väntar barn 1995, 1997. [We Are Expecting a Baby.] Helsinki: Stakes.

Wessman, Vilhelm Eliel Viktorinus (ed.) 1952. Finlands svenska folkdiktning. [The Folklore of Swedish Finland.] VII. Folktro och trolldom. 3. Människan och djuren. Helsinki: Svenska Litteratursällskapet. Available at http://folkdiktning.sls.fi/\#/ publication/47/cover/, last accessed on 14 October 2020.

Wrede, Sirpa 1998. "Hon är inte en i hopen": Barnmorskor som publicerar minnen. [She Wasn't One in the Huddle: Midwives' Published Memories.] In: Harriet Silius \& Ann-Catrin Östman \& Kristin Mattsson (eds.) I dialog med kvinnoliv. Åbo: Åbo Akademi, pp. 112-142. 
Lena Marander-Eklund is Professor in folkloristics at Åbo Akademi University in Turku, Finland. Her research interests are narratives and narration, methodological aspects of interviews and questionnaires, life stories, emotions, weather folklore and folk medicine.

lena.marander-eklund@abo.fi 